\title{
Effect of Gooseberry (Physalis angulata) Ethanol Extract in Wistar Rats Carrageenan-Induced Paw Oedema
}

\author{
Ami Nurlatifah, ${ }^{1}$ Eka Hendryanny, ${ }^{2}$ Yuniarti $^{3}$ \\ ${ }^{1}$ Medical Undergraduate Study Program, Faculty of Medicine, Universitas Islam Bandung, Bandung, Indonesia, \\ ${ }^{2}$ Department of Physiology, Faculty of Medicine, Universitas Islam Bandung, Bandung, Indonesia, \\ 3Department of Anatomy, Faculty of Medicine, Universitas Islam Bandung, Bandung, Indonesia
}

\begin{abstract}
Gooseberry is an herbaceous plant that contains flavonoids. Flavonoid is one of the secondary metabolites that have an anti-inflammatory effect. This study aims to determine the effect of using ethanol extract of gooseberry as an anti-inflammatory in carrageenan-induced paw edema. This study was in vivo experimental laboratory using a completely randomized design of 25 Wistar rats and divided into five groups. The negative control group was given carboxymethylcellulose. The positive control group has given diclofenac sodium $27 \mathrm{mg} / 200 \mathrm{gBW}$. The sample test group has given ethanol extract of gooseberry with $3.6 \mathrm{mg} / 200 \mathrm{gBW}, 5.4 \mathrm{mg} / 200 \mathrm{gBW}$, and 7.2 mg/200 gBW dosage. Paw rat's inflammation induced by injecting carrageenan and measured from 1 st to $6^{\text {th }}$ hour using a pletismometer. This study has conducted at Pharmacology Laboratory, Universitas Islam Bandung, and the Laboratory of Therapy and Pharmacology, Universitas Padjajaran, from June to September 2019. The result of average edema volume paw rats using the Kruskal-Wallis test on the 6th hour was $\mathrm{p}=0.02(\mathrm{p}<0.05)$. The Mann-Whitney test was $\mathrm{p}<0.05$, showing differences between negative control and positive control and sample test groups. One-way ANOVA test on the percentage of edema inhibition between positive control and sample test group had $\mathrm{p}=0.107$. It shows no significant difference. An effect of ethanol of extract of gooseberries as an anti-inflammatory with the highest percentage of edema inhibition is $5.4 \mathrm{mg} / 200 \mathrm{gBW}$ dosage. The flavonoid content in gooseberries is thought to inhibit the formation of prostaglandins by inhibiting the cyclooxygenase enzyme. In conclusion, the ethanol extract of gooseberry can be anti-inflammatory.
\end{abstract}

Key words: Anti-inflammatory, diclofenac sodium, gooseberry ethanol extract, Wistar rat

\section{Efek Ekstrak Etanol Ciplukan (Physalis angulata) terhadap Edema Telapak Kaki Tikus Galur Wistar yang Diinduksi Karagenan}

\begin{abstract}
Abstrak
Ciplukan adalah tanaman herbal yang mengandung flavonoid. Flavonoid merupakan salah satu metabolit sekunder yang dapat memberikan efek antiinflamasi. Penelitian ini bertujuan mengetahui pengaruh penggunaan ekstrak etanol ciplukan sebagai antiinflamasi pada tikus yang diinduksi karagenan. Penelitian ini merupakan penelitian laboratorium eksperimental in vivo menggunakan desain rancangan acak lengkap pada 25 ekor tikus galur Wistar yang terbagi ke dalam lima kelompok. Kelompok kontrol negatif diberi carboxymethilcellulose. Kontrol positif diberi sodium diklofenak $27 \mathrm{mg} / 200 \mathrm{gBB}$. Kelompok uji diberi ekstrak etanol ciplukan dengan dosis 3,6 mg/200 $\mathrm{gBB} ; 5,4 \mathrm{mg} / 200 \mathrm{gBB}$; dan 7,2 mg/200 gBB. Induksi inflamasi dilakukan dengan menginjeksikan karagenan pada telapak kaki tikus, lalu diukur menggunakan pletismometer dari jam ke-1 hingga jam ke-6. Penelitian ini dilakukan di Laboratorium Farmasi, Universitas Islam Bandung dan Laboratorium Farmasi dan Terapi, Universitas Padjajaran dari bulan Juni hingga September 2019. Volume rerata telapak kaki tikus pada jam ke-6 menggunakan Uji KruskalWallis adalah $\mathrm{p}=0,02(\mathrm{p}<0,05)$. Hasil Uji Mann-Whitney diperoleh $\mathrm{p}<0,05$ yang menunjukkan terdapat perbedaan bermakna antara kontrol negatif dan kontrol positif serta kelompok uji. Uji one-way ANOVA pada persentase penghambatan edema antara kontrol positif dan kelompok uji diperoleh $\mathrm{p}=0,107$ yang menunjukkan tidak terdapat perbedaan yang bermakna. Terdapat pengaruh ekstrak etanol ciplukan sebagai antiinflamasi dengan persentase penghambatan edema tertinggi pada dosis $5,4 \mathrm{mg} / 200 \mathrm{gBB}$. Kandungan flavonoid pada ciplukan diduga mampu menghambat pembentukan prostaglandin dengan menginhibisi enzim siklooksigenase. Simpulan penelitian ini adalah ekstrak etanol ciplukan dapat digunakan sebagai antiinflamasi.
\end{abstract}

Kata kunci: Antiinflamasi, ekstrak etanol ciplukan, sodium diklofenak, tikus galur Wistar

Received: 27 June 2020; Revised: 3 February 2021; Accepted: 11 March 2021; Published: 30 April 2021

Correspondence: Ami Nurlatifah. Medical Undergraduate Study Program, Faculty of Medicine, Universitas Islam Bandung. Jln. Tamansari No. 22, Bandung 40116, West Java, Indonesia. E-mail: ami19nurlatifah@gmail.com 


\section{Introduction}

The human body has a protective response to the dangerous agent that works when there is an infection, physical pressure, and injury. The protection response is called inflammation. Inflammation is signed by rubor, calor, dolor, tumor, and functio laesa. Several studies have provided evidence that inflammation is involved in the pathogenesis of various diseases, including aging, cancer, and cardiovascular dysfunction. Inflammation can be divided into acute and chronic phases. Acute inflammation cannot be sustainable because it can cause a chronic condition that triggers the chronic inflammatory disease. Chronic inflammation that arises in certain areas can result in a dangerous disease, such as if it occurs in a blood vessel, it will increase the risk of atherosclerosis. If it occurs in the joint area, it can cause rheumatic disease. ${ }^{1-11}$

It is necessary to use anti-inflammatory to reduce the sign of inflammation and tissue damage. Anti-inflammation commonly used in modern medicine is divided into two different types: glucocorticoid and nonsteroidal antiinflammatory drugs (NSAIDs). Diclofenac sodium is one of the NSAIDs types commonly used, but this one can cause ulceration in the digestive tract and inhibit blood coagulation if consumed for long periods..$^{12-15}$

Many people choose to use bioactive molecular medicinal plants in medicine throughout the country, especially in rural areas in developing countries with low socio-economic factors that make it difficult to access the health care system and modern medicines. One of the medicinal plants which have anti-inflammatory properties is gooseberry (Physalis angulata). ${ }^{16,17}$

Gooseberry is an herbaceous plant that is easily obtained and can be purchased at low prices in Indonesia. All of the gooseberries, such as the roots, stems, fruits, and leaves, are rich in chemical compounds beneficial for therapy. The content of gooseberry, which provides an anti-inflammatory effect, comes from flavonoids. Flavonoids are secondary metabolites formed through fatty acid metabolism that can inhibit the cyclo-oxygenase (COX) enzyme. Flavonoids also inhibit xanthine oxidase (XO), lipoxygenase, and phosphoinositide-3-kinase. ${ }^{16-20}$

One study mentioned that ethanol had the highest percentage in attracting active flavonoid substances from gooseberry.$^{10}$ For this reason, this research use ethanol as a solvent from gooseberry extract. Based on this background, the purpose of this study was to determine the effect of ethanol extract of gooseberry as an anti-inflammation in carrageenan-induced rats, to know the concentration of ethanol extract of gooseberry, which faster to eliminate inflammation, and to analyze the difference of anti-inflammatory effects between ethanol extract of gooseberry and diclofenac sodium on carrageenan-induced paw edema in Wistar rats.

\section{Methods}

The research was conducted from June to September 2019 after received ethical clearance from the Health Research Ethics Committee of Faculty Medicine, Universitas Islam Bandung, Number: 039/Komite Etik FK/IV/2019. This research method was purely in vivo experiments conducted in a laboratory using a complete randomized design. It began with collecting gooseberry plant from Yogyakarta and then determining it in Institut Teknologi Bandung by a process called determination plants to ensure the plants were Physalis angulata species. The gooseberry ethanol extract was made using one kilogram of dried gooseberry leaves processed into powder using an electric blender and dissolved with $95 \%$ ethanol in 3 days. The extract filtered then evaporated using a vacuum rotary evaporator to separate the solvent from the extract. This process is repeated three times, with the result was a brown paste. The phytochemical screening was conducted in Pharmacology Laboratory Universitas Islam Bandung to ensure that the extract contained flavonoids. In this study, both extract ethanol of gooseberry and diclofenac sodium diluted with carboxymethyl cellulose $0.5 \%$ to make sure it had a similar liquid type with the negative control group. The suspension of $\lambda$ carrageenan was from the Laboratory of Therapy and Pharmacology Universitas Padjajaran. It is made from 5-gram carrageenan powder and diluted with $500 \mathrm{~mL}$ saline $0.9 \%$. Randomization of 25 rats used paper shuffle for five numbers of groups and five numbers of rats. The adaptation rats' period was carried out for seven days on the cage in the Laboratory of Therapy and Pharmacology Universitas Padjajaran with research standards, 12 hours in a dark room and 12 hours in a bright room. It was given standard feed and water. A 
day after the rats' adaptation period completed, the study was carried out by conducting initial measurements on the volume of rats paw, followed by $0.5 \%$ carboxymethylcellulose administration with $2 \mathrm{~mL} / 200 \mathrm{gBW}$ to the negative control group, sodium diclofenac $27 \mathrm{mg} / 200 \mathrm{gBW}$ to the positive control group, and gooseberry ethanol extract with the dosages of $3.6 \mathrm{mg} / 200 \mathrm{gBW}$, $5.4 \mathrm{mg} / 200 \mathrm{gBW}$, and $7.2 \mathrm{mg} / 200 \mathrm{gBW}$ to the first, second and third groups. Thirty minutes after oral treatment, all of the rats were induced to inflammation by injecting $0.1 \mathrm{~mL}$ subplantar carrageenan (Figure 1).

The measurements were retaken after carrageenan induction and continued every hour, started from the first hour until 6 hours after carrageenan induction..$^{21-24}$ After all the research step was done, to fulfill a good animal ethical procedure, the rats have been euthanasia with injected $1 \mathrm{~mL}$ of ketamine then buried the rats.

The results were displayed by the average edema volume of rats paw in the $1^{\text {st }}, 2^{\text {nd }}, 3^{\text {rd }}, 4^{\text {th }}$, $5^{\text {th }}$, and $6^{\text {th }}$ hours. The study's normality used the Shapiro-Wilk test, and the homogeneity used the Levene test on IBM SPSS statistics 25 application with a confidence interval of $95 \%$. The normal and homogenous data used a one-way ANOVA test, while the abnormal nor homogenous data used the Kruskal-Wallis test. The Mann-Whitney test tested the significant result of Kruskal-Wallis..

\section{Results}

Institut Teknologi Bandung gave the result of the determination, and it showed the gooseberry's type we brought was Physalis angulata. The production of ethanol extract of gooseberry was carried out in the Laboratory of Therapy and Pharmacology Universitas Padjajaran, followed by a phytochemical screening in Pharmacology Laboratory Universitas Islam Bandung, which showed that the extract contained flavonoid. Research on the anti-inflammatory activity of ethanol extract of gooseberry was conducted on 25 carrageenan-induced male Wistar rats. All of the anti-inflammatory samples tests were given 30 minutes before carrageenan induction to see the percentage of edema inhibition and the measurement as in Figure 2.

The measurements were taken every hour for 6 hours by dipping the paw rats into the tube of the pletismometer. The measurement result of the paw rat volume was in Table 1.

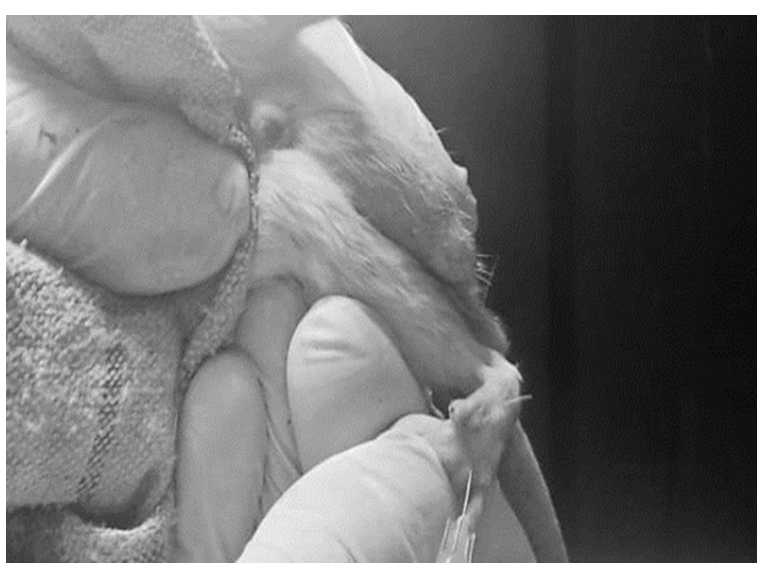

Figure 1 Injection of Carrageenan

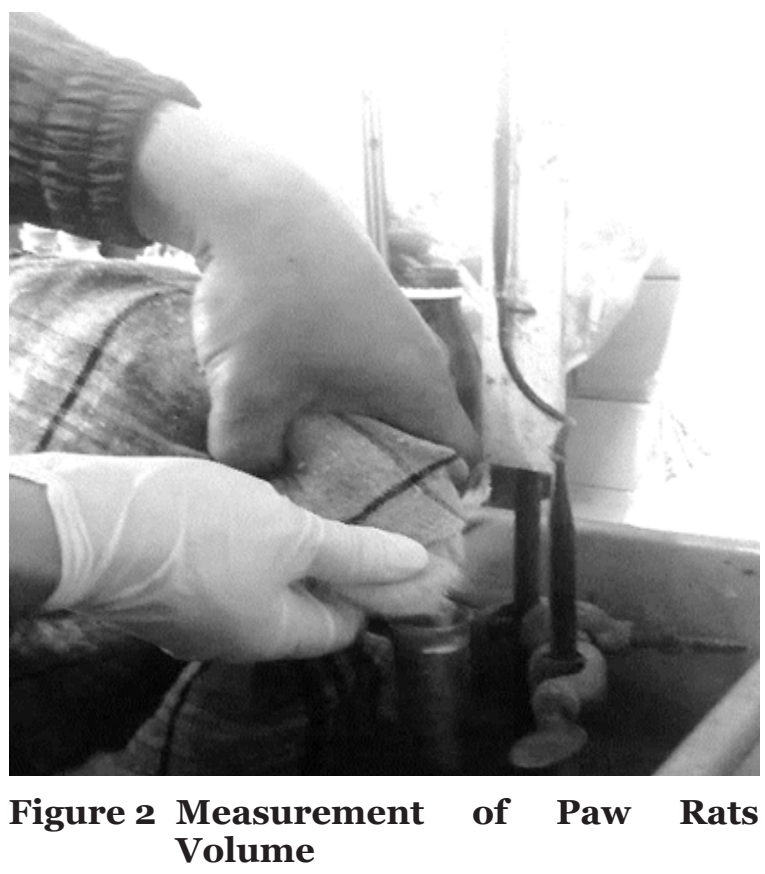

In the $4^{\text {th }}$ hours, the rat's paw volume from all groups was at the edema peak. The volume of paw rats in the positive control group, the first sample test, the second sample test, and the third sample test decreased than the negative control group at the $6^{\text {th }}$ hours. Comparing the average paw rat volume at the initial measurements and the $6^{\text {th }}$ hours showed the highest increase in the negative control group and the lowest in the second sample test group. There was a difference in rat paw edema volume of about two $\mu \mathrm{L}$ between the second sample test group and the positive control group. 
Table 1 Result of Paw Rat Volume Measurement

\begin{tabular}{|c|c|c|c|c|c|c|c|c|}
\hline \multirow{3}{*}{$\begin{array}{l}\text { Rat } \\
\text { Groups }\end{array}$} & \multicolumn{8}{|c|}{ Volume of Rat Paw $(\mu \mathrm{L})$} \\
\hline & \multirow{2}{*}{$\mathbf{I M}^{*}$} & \multirow{2}{*}{$\mathbf{B C I}^{* *}$} & \multicolumn{6}{|c|}{ Hour } \\
\hline & & & $\mathbf{1}$ & 2 & 3 & 4 & 5 & 6 \\
\hline $\begin{array}{l}\text { Negative } \\
\text { control }\end{array}$ & $56.0 \pm 13.4$ & $80.0 \pm 12.3$ & $108.0 \pm 16.4$ & $114.0 \pm 8.2$ & $122.0 \pm 13.0$ & $134.0 \pm 8.9$ & $128.0 \pm 13.0$ & $132.0 \pm 16.4$ \\
\hline $\begin{array}{l}\text { Positive } \\
\text { control }\end{array}$ & $82.0 \pm 8.4$ & $96.0 \pm 8.9$ & $124.0 \pm 11.4$ & $122.0 \pm 13.0$ & $116.0 \pm 13.4$ & $132.0 \pm 8.4$ & $114.0 \pm 11.4$ & $104.0 \pm 5.5$ \\
\hline $\begin{array}{l}1^{\text {st }} \text { sample } \\
\text { test }\end{array}$ & $70.0 \pm 10.0$ & $96.0 \pm 13.4$ & $124.0 \pm 16.7$ & $124.0 \pm 15.2$ & $122.0 \pm 14.8$ & $128.0 \pm 19.2$ & $120.0 \pm 12.3$ & $104.0 \pm 8.9$ \\
\hline $\begin{array}{l}2^{\text {nd }} \text { sample } \\
\text { test }\end{array}$ & $76.0 \pm 5.5$ & $90.0 \pm 7.1$ & $112.0 \pm 14.8$ & $114.0 \pm 15.2$ & $118.0 \pm 16.4$ & $124.0 \pm 16.7$ & $110.0 \pm 12.3$ & $100.0 \pm 12.3$ \\
\hline $\begin{array}{l}3^{\text {rd }} \text { sample } \\
\text { test }\end{array}$ & $64.0 \pm 11.4$ & $82.0 \pm 8.4$ & $100.0 \pm 7.1$ & $106.0 \pm 5.5$ & $114.0 \pm 11.4$ & $124.0 \pm 8.94$ & $110.0 \pm 7.2$ & $102.0 \pm 4.5$ \\
\hline
\end{tabular}

Note: "initial measurement, "*before carrageenan induction

Based on Table 1, it can be calculated the percentage of the average edema inhibition on the rat paw through the formula: ${ }^{25}$

$\%$ edema inhibition average $=\left\{1-\left(\frac{a-x}{b-y}\right)\right\} \times 100 \%$

Description: a=the rat's paw average volume at a certain hour in the positive control group and the test group, $\mathrm{x}=$ the rat's paw average volume at the positive control group's initial measurements and the test group, $b=$ the rat's paw's average volume at a certain hour in the negative control group, $y=$ the average volume of the rat's paw at the negative control group's initial measurements
The percentage of rat's paw edema inhibition is shown in Figure 3.

In Figure 3, in the $1^{\text {st }}$ hours of measurement, the highest percentage of inhibition came from the second sample test group (30.77\%) and the third sample test (30.77\%), followed by the positive control group (19.23\%) and the first sample test group $(-3.85 \%)$. While the edema peaked in the $4^{\text {th }}$ hours, the percentage edema inhibition in the positive control group (35.9\%) and the third sample test (23.08\%) decreased.

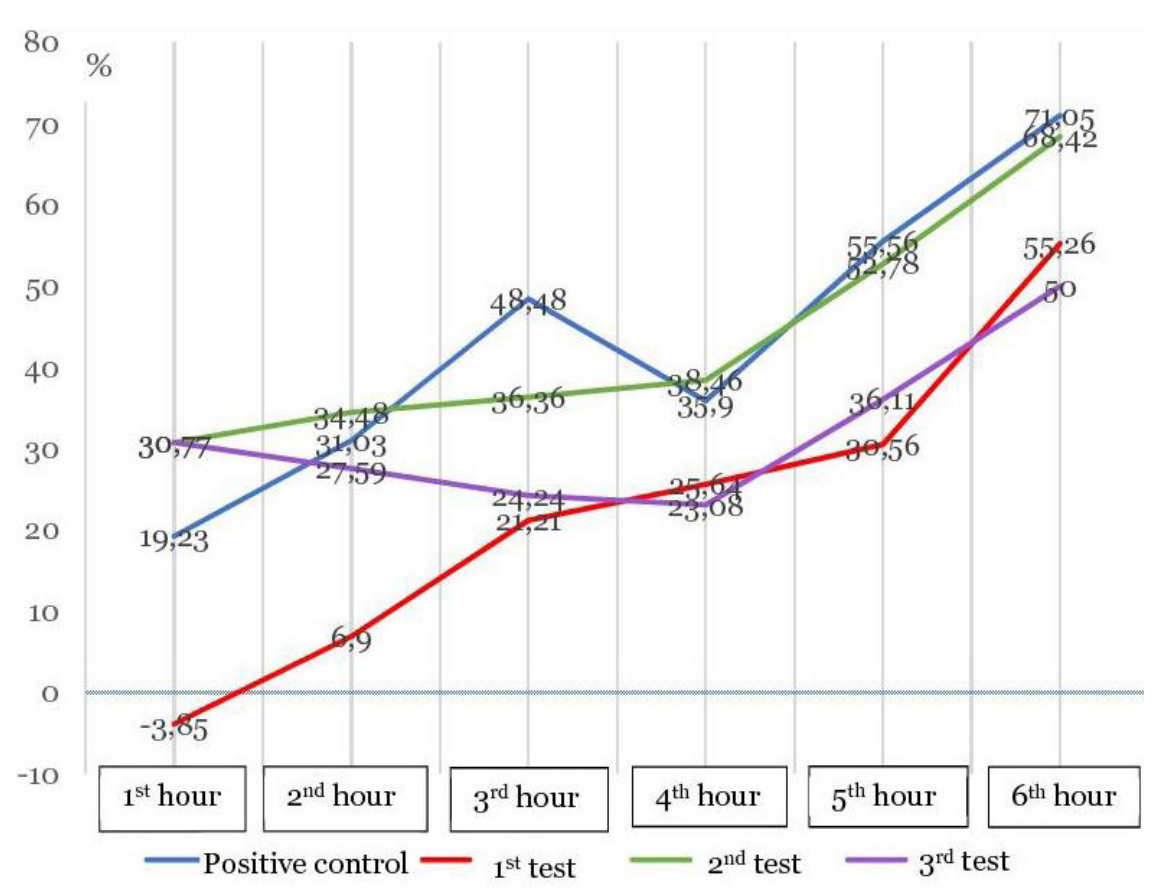

Figure 3 Percentage of Paw Rat Edema Inhibition 
Table 2 Volume Difference on Paw Rats

\begin{tabular}{ccc}
\hline $\begin{array}{c}\text { Measurement } \\
\text { Time }\end{array}$ & $\mathbf{p}^{*}$ & $\mathbf{p}^{* *}$ \\
\hline $1^{\text {st }}$ & & 0.068 \\
$2^{\text {nd }}$ & & 0.260 \\
$3^{\text {rd }}$ & 0.855 & \\
$4^{\text {th }}$ & & 0.651 \\
$5^{\text {th }}$ & & 0.100 \\
$6^{\text {th }}$ & & 0.022 \\
\hline
\end{tabular}

Note: ${ }^{*}$ one-way ANNOVA test, $\mathrm{p}<0.05$ significant, ${ }^{* *}$ KruskalWallis test, $\mathrm{p}<0.05$ significant

However, it turned back to the extreme increase in edema inhibition until the last hour, followed by the second sample test group (68.47\%). In the $5^{\text {th }}$ hours, the first sample test group's percentage edema inhibition increased (30.56\%). In the $6^{\text {th }}$ hours, the positive control group (71.05\%) showed the highest percentage of edema inhibition, followed by the second sample test group (68.42\%), the first sample test (55.26\%), and the third sample test (50\%). When the sample test compared to the positive control, the first sample test group's edema inhibition rate was $16 \%$ lower than the positive control. The second sample test was $3 \%$ lower than the positive control, and the third sample test was $21 \%$ lower than the positive control.

The normality and homogeneity tests were performed on the edema volume. It showed normal and homogeneous distributed data only in the third hour. Then one-way ANOVA test was performed with a value of $\mathrm{p}=0.855(\mathrm{p}<0.05)$, which meant there was no significance. In the 6th hour measurement, data were not distributed normally nor homogenous, and it continued with the Kruskal-Wallis test with $\mathrm{p}$ value $=0.022$ $(\mathrm{p}<0.05)$. The difference between the one-way ANOVA test and the Kruskal-Wallis test in Table 2. Data in the $6^{\text {th }}$ hour had a significant resultthe Mann-Whitney test showing a significant difference between negative control and positive control and sample test groups. Also, there was no significant difference between the positive control and sample test group.

The normality and homogeneity tests were also performed on the edema inhibition percentage data, and the results showed normal and homogeneous distribution. A one-way ANOVA test was then performed with a value of $\mathrm{p}=0.107$ $(\mathrm{p}<0.05)$, which meant no significant difference from the percentage of inhibition edema in the positive control group with the first, second and third sample tests group. It showed that ethanol extract of gooseberry provides anti-inflammatory effects such as diclofenac sodium.

\section{Discussion}

Induction of inflammation using carrageenan on the paw to make edema. In Table 1, the volume of the paw increased immediately after carrageenan injection. The peak of edema occurs at the 4th hour when carrageenan triggers maximal prostaglandin release. The process consists of the first phase mediated by histamine and 5-hydroxytryptamine, followed by a second phase mediated by kinin triggering the activation of the enzyme cyclooxygenase and the third phase of local prostaglandin production. The prostaglandin precursor is a derivative of arachidonic acid, which is activated by the enzyme cyclooxygenase. ${ }^{2,3}$

Gooseberry is an herbaceous plant that has various substances, one of that is a flavonoid. ${ }^{15,17,18}$ The role of flavonoids in inhibiting the cyclooxygenase enzyme can be used as an antiinflammatory. Flavonoid will break the chain of inflammation by inhibiting the cyclooxygenase enzyme so that prostaglandins will not be formed. Flavonoid is COX-2 selective, so it can be used as an anti-inflammatory that reduces the effects of ulceration in the digestive tract and bleeding. ${ }^{3}$ In bio-molecular studies, the marker used in antiinflammatory testing is nuclear factor-kappaB $(\mathrm{NF}-\mathrm{kB})$. Research shows the content of physalin E (a type of secosteroid that can form flavonoids through fatty acid metabolism in physalis plants (gooseberry) can inhibit the transcription factor $\mathrm{NF}-\kappa \mathrm{B}$ which plays an essential role in the inflammatory process. When NF- $\mathrm{kB}$ bind to tumor necrosis factor- $\alpha$ (TNF- $\alpha$ ) and interferon$\gamma(\mathrm{IFN}-\gamma)$, it can induce the transcription of proinflammatory genes, so that inhibition of NF- $\mathrm{KB}$ can prevent inflammation. These studies support that the reduced edema volume in the sample test group comes from flavonoid in ethanol extract of gooseberry. ${ }^{26}$

Gooseberry (Physalis angulata) has active substances such as physalin 9 and 10 that act as antiproliferative, and physalin 1, 3, 4, 9, 10, 13, 14, 16 act as an anti-inflammatory which works by inhibiting the production of nitrite oxide. The damage of deoxyribonucleic acid (DNA) and cell membranes is mediated by nitric oxide to trigger 
nuclear pro-inflammatory cytokines, which can activate and recruit inflammatory cells. If nitric oxide production is inhibited, the inflammatory process can be stopped. ${ }^{27}$

Dosage of $400 \mathrm{mg} / \mathrm{kgBW}$ of methanol extract of gooseberries by Ukwubile and Oise ${ }^{18}$ showed the same anti-inflammatory effect as ethanol extract of gooseberries in this research. The percentage of edema inhibition produced in Ukwubile and Oise' $\mathrm{s}^{18} \mathrm{study}$ was $62.7 \%$. This is different from the research results that gooseberry's ethanol extract gave the highest percentage of edema inhibition, with $68.4 \%$ from the second sample test group given a dosage of $5.4 \mathrm{mg} / 200 \mathrm{gBW}$ (300 mg/ $\mathrm{kgBW}$ ). It can be caused by the differences in the solvent so that the binding of flavonoids nonoptimal.

\section{Conclusions}

We conclude an anti-inflammatory effect of ethanol extract of gooseberry on carrageenaninduced paw edema in Wistar rats. There was no significant difference between the diclofenac sodium group and the gooseberry ethanol extract, which meant both had anti-inflammatory effects on edema.

\section{Conflict of Interest}

There is not any conflict of interest in this research.

\section{Acknowledgements}

The authors thank the Faculty of Mathematics and Natural Sciences and the research institution of Universitas Islam Bandung and Padjajaran University Laboratory of Therapy and Pharmacology staff.

\section{References}

1. Kotas ME, Medzhitov R. Homeostasis, inflammation, and disease susceptibility. Cell. 2015;160(5):816-27.

2. Rote NS, Huether SE, McCance KL. Innate immunity: inflammation. In: McCance KL, Huether SE, Brashers VL, Rote NS, editors. Pathophysiology: the biologic basis for disease in adults and children. $7^{\text {th }}$ Edition. Philadelphia: Mosby; 2014. p. 191-223.

3. Kumar V, Abbas AK, Aster AC, editors.
Robbins basic pathology. $10^{\text {th }}$ Edition. Philadelphia: Elsevier; 2017.

4. Sherwood L. Human physiology: from cells to system. $9^{\text {th }}$ Edition. Boston: Cengage Learning; 2016.

5. Hall JE. Guyton and Hall textbook of medical physiology. $13^{\text {th }}$ Edition. Philadelphia: Elsevier; 2015.

6. Tortora GJ, Derrickson B. Principle of anatomy and physiology. $15^{\text {th }}$ Edition. Joboken: John Wiley \& Sons; 2017.

7. Marieb EN, Hoehn K. Human anatomy and physiology. $10^{\text {th }}$ Edition. London: Pearson; 2015.

8. Grossman SC, Porth CM. Porth's pathophysiology: concepts of altered health states. $9^{\text {th }}$ Edition. Philadelphia: Wolters Kluwer Health, Lippincott Williams \& Wilkins; 2014.

9. Mescher AL. Junqueira's basic histology: text and atlas. $15^{\text {th }}$ Edition. New York: McGrawHill Education; 2018.

10. Haynes BF, Soderberg KA, Fauci AS. Introduction to the immune system. In: Kasper DL, Fauci AS, Hauser SL, Longo DL, Jameson JL, Loscalzo J, editors. Harrison's principles of internal medicine. $18^{\text {th }}$ Edition. Volume 2. New York: McGraw-Hill Education; 2012. p. 2650-85.

11. Pfizer. Burden of disease: chronic inflammation and inflammatory disease [Internet]. New York: Pfizer; 2017 [cited 2019 January 25]. Available from: https:// pfe-pfizercom-prod.s3.amazonaws.com/ health/VOM_Chronic_Inflammation_and_ Inflammatory_Diseases.pdf.

12. Stoelting RK, Flood P, Rathmell JP, Shafer S. Stoelting's handbook of pharmacology and physiology in anesthetic practice. $3^{\text {rd }}$ Edition. Philadelphia: Wolters Kluwer Health; 2015.

13. Dietrich E, Carris N, Panavelil TA. Antiinflammatory, antipyretic, and analgesic agents. In: Whalen K, Finkel R, Panavelil TA, editors. Lippincott illustrated reviews: pharmacology. $6^{\text {th }}$ Edition. Philadelphia: Lippincott Williams \& Wilkins; 2015. p. 447-69.

14. Furst DE, Ulrich RW, Prakash S. Nonsteroidal anti-inflammatory drugs, disease-modifying antirheumatic drugs, nonopioid analgesics, and drugs used in gout. In: Katzung BG, Masters SB, Trevor AJ, editors. Basic and clinical pharmacology. $12^{\text {th }}$ Edition. New 
York: McGraw-Hill; 2012. p. 635-57.

15. Rivera DE, Ocampo YC, Castro JP, Barrios L, Diaz F, Franco LA. A screening of plants used in Colombian traditional medicine revealed the anti-inflammatory potential of Physalis angulata calyces. Saudi J Biol Sci. 2019;26(7):1758-66.

16. Keputusan Menteri Kesehatan Republik Indonesia Nomor HK.01.07/ MENKES/187/2017 tentang Formularium Ramuan Obat Tradisional Indonesia.

17. Aliero AA, Usman H. Leaves of ground cherry (Physalis angulata L.) may be suitable in alleviating micronutrient deficiency. Food Sci Technol. 2016;4(5):89-94.

18. Ukwubile CA, Oise IE. Analgesic and antiinflammatory activity of Physalis angulata linn. (solanaceae) leaf methanolic extract in Swiss albino mice. Int Biol Biomed $\mathrm{J}$. 2016;2(4):167-70.

19. Leyva-Jiménez FJ, Lozano-Sánchez J, CádizGurrea MDLL, Arráez-Román D, SeguraCarretero A. Functional ingredients based on nutritional phenolics. A case study against inflammation: Lippia genus. Nutrients. 2019;11(7):1646.

20. IL Smales, MG Rowland. The Selection of Excipients for Oral Solid Dosage Forms. In: Sheskey PJ, Cook WG, Cable CG, editors. Handbook of pharmaceutical excipients. $8^{\text {th }}$ Edition. London: Pharmaceutical Press; 2017. p. 10-24.

21. Shah HC, Singh KK. Carrageenan. In: Sheskey PJ, Cook WG, Cable CG, editors. Handbook of pharmaceutical excipients. $8^{\text {th }}$ Edition. London: Pharmaceutical Press;
2017. p. 178-82.

22. National Research Council (US) Committee for the Update of the Guide for the Care and Use of Laboratory Animals. Guide for the care and use of laboratory animals. $8^{\text {th }}$ Edition. Washington DC: National Academies Press; 2011.

23. Guan J, Li L, Mao S. Applications of carrageenan in advanced drug delivery. In: Venkatesan J, Anil S, Kim SK, editors. Seaweed polysaccharides: isolation, biological and biomedical applications. Amsterdam: Elsevier; 2017. p. 283-303.

24. Begum R, Sharma M, Pillai KK, Aeri V, Sheliya MA. Inhibitory effect of Careya arborea on inflammatory biomarkers in carrageenan-induced inflammation. Pharm Biol. 2015;53(3):437-45.

25. Saputri FC, Zahara R. Uji aktivitas antiinflamasi minyak atsiri daun kemangi (Ocimum americanum L.) pada tikus putih jantan yang diinduksi karagenan. PSR. 2016;3(3):107-19.

26. Yang YJ, Yi L, Wang W, Xie BB, Dong $\mathrm{Y}$, Sha CW. Anti-inflammatory effects of physalin E from Physalis angulata on lipopolysaccharide-stimulated RAW 264.7 cells through inhibition of $\mathrm{NF}-\kappa \mathrm{B}$ pathway. Immunopharmacol Immunotoxicol. 2017; 39(2):74-9.

27. Sun CP, Qiu CY, Zhao F, Kang N, Chen LX, Qiu F. Physalins V-IX, 16,24-cyclo-13, 14-seco withanolides from Physalis angulata and their antiproliferative and anti-inflammatory activities. Sci Rep. 2017;7(1):4057. 